\title{
What attracts multinational enterprises from the new EU member states to Poland?
}

\author{
Andrzej Cieślik ${ }^{1}[$
}

Received: 6 August 2018 / Revised: 28 January 2019 / Accepted: 8 March 2019 /

Published online: 25 March 2019

(c) The Author(s) 2019

\begin{abstract}
The main goal of this study is to examine empirically the determinants of multinational activity of firms from the new EU-12 member states in Poland during the period 1990-2014 using the negative binomial model. In particular, we test the predictions of competing theoretical models of the multinational enterprise to identify the investment motives for undertaking foreign direct investment in Poland. In addition to traditional country-pair characteristics such as absolute and relative market size and differences in relative factor endowments, in this study we account for cultural differences between the host and partner countries that may affect the cost of foreign investment. The assembled empirical evidence points to both market access and efficiency seeking as the main reasons for undertaking foreign direct investment in Poland by multinational enterprises based in the new EU-12 member states. However, cultural proximity does not seem to be an important factor in explaining the extent of multinational activity in Poland.
\end{abstract}

Keywords Cultural proximity $\cdot$ Factor endowments $\cdot$ Multinational enterprises · New EU member states · Poland

JEL Classification F23 · P33

\section{Introduction}

Multinational enterprises (MNEs) with their rapidly increasing shares in world output, investment and trade flows have become key actors in the ongoing process of globalization in the world economy. The largest share of multinational activity has traditionally been occurring between developed countries that have been at the same time both the main sources and the recipients of foreign direct investment (FDI). However, with the falling transportation and communication costs between the

Andrzej Cieślik

cieslik@wne.uw.edu.pl

1 Faculty of Economic Sciences, University of Warsaw, Warsaw, Poland 
developed and developing countries, an increasing fraction of FDI becomes located in the emerging market economies. These include also the former centrally planned economies in Central and Eastern Europe (CEE) that have successfully completed their transition process towards market economy and became integrated into the European Union (EU).

The opening up of the economies of these countries to international trade and investment gave MNEs both access to new markets and cheap production opportunities. Consequently, FDI flows to this region have been continuously growing. With over 167 billion euros in inward foreign direct investment at the end of 2015, Poland has become one of the most attractive host countries for the location of MNE activities among the new European Union (EU) member countries in the last decades (National Bank of Poland 2017). Although the majority of FDI in Poland originates from the old EU-15 countries, the involvement of MNEs from the new EU-12 member countries has been steadily increasing.

While many theories have been proposed to explain the emergence of MNEs, two main reasons why a firm should internationalize production have been proposed in the theoretical literature: efficiency seeking and market access (Dunning and Lundan 2008; Markusen 2013).

According to the first one, firms internationalize production and become MNEs to get inputs at a lower cost. According to the second one, MNEs can be regarded as vehicles to overcome distance and lower costs of foreign markets access. These two alternative reasons have very different empirical implications.

Therefore, the purpose of this study is to test the predictions of several competing theoretical models of the multinational enterprise and identify the investment motives for undertaking FDI in Poland using bilateral dataset on the activity of MNEs from the new EU-12 member states covering the period 1990-2014. The majority of empirical studies on FDI determinants in Poland have so far focused on the investments made by multinational enterprises coming from the developed countries, and in particular from the old EU-15. At the same time, the empirical evidence on determinants of inward FDI in Poland that originates from the new EU member countries still remains scarce. Hence, the present study aims at extending and complementing the previous empirical research on the determinants of multinational activity in Poland.

This paper is structured as follows. In Sect. 2, we provide the summary of the relevant MNE literature and discuss the competing theoretical frameworks. In Sect. 3, we describe the definitions and sources of our explanatory variables and discuss the statistical methodology. In Sect. 4, we report our empirical results. The summary of the main findings and potentially fruitful future research avenues are located in the concluding section.

\section{Literature summary and theoretical background}

Early studies that belong to the neoclassical strand in the literature view FDI as a part of the portfolio theory of international capital flows that are driven by international differences in the rates of return on capital. The early examples of theoretical 
studies on FDI that belong to the neoclassical strand in the FDI literature include, inter alia, Mundell (1957), MacDougall (1960) or Kemp (1962). In particular, capital should flow from capital-rich to capital-scarce countries. At the same time, according to this view, capital flows between countries with the same factor endowments should not be observed. However, these predictions are not in line with reality since the largest share of MNE activity occurs between similar countries in terms of their relative factor endowments and rates of return on capital. In addition, the neoclassical approach to FDI was also criticized because of relying on the set of unrealistic assumptions. These include constant returns to scale (CRS) and perfect competition, which were not in line with the key stylized facts on FDI (Markusen 1995, 1998, 2002, 2013).

The rejection of the neoclassical approach by the majority of economists led to the development of alternative frameworks in the international business and international economics literatures. The major representative of the international business literature is Dunning's (1977) Ownership-Location-Internalization (OLI) eclectic framework that later became also the frequent point of departure for formal theoretical modeling in the so-called New Trade Theory (NTT) literature that emerged in the early 1980s. The NTT provided a set of modeling tools that proved very useful in studying the emergence of MNEs which initiated the development of the modern theory of multinational enterprise starting from the mid-1980s. These tools allowed theoretical modeling of two main reasons why a firm should internationalize production: market access and efficiency seeking within the frameworks of both horizontally- and vertically-integrated MNEs. Horizontal integration refers to producing abroad roughly the same goods and services as in the home country while vertical integration involves fragmentation of production processes and location of each stage in a country where the factors of production used intensively in that particular stage are relatively cheap (Caves 2007; Markusen 2002, 2013).

Initially, the models of horizontally integrated MNEs were based on partial equilibrium frameworks and assumed identical factor endowments across countries and later they were extended to the general equilibrium setting. ${ }^{1}$ The theoretical modeling of horizontally integrated MNEs involves a tradeoff between the saving on the trade cost and the cost of establishing a new plant in the host country. The theory of horizontally integrated MNEs predicts that given moderate to high trade costs, multinational activity will prevail in the equilibrium when countries are similar in size and in relative factor endowments.

Vertically integrated MNEs split up their production processes into separate segments that can be located in different countries according to their comparative advantages. The theoretical modeling of vertically-integrated MNEs assumes that different segments of production processes have different input requirements so it may be profitable to locate each segment where particular factors used intensively

\footnotetext{
1 The earliest examples of this approach include theoretical models developed by Krugman (1983) and Markusen (1984) that were later extended, inter alia, by Horstmann and Markusen (1987), Brainard (1993a), Markusen and Venables (1998, 2000), Helpman et al. (2004), Cieślik (2013, 2015a, b, 2016, 2018) and Cieślik and Ryan (2012).
} 
in that stage are relatively inexpensive. ${ }^{2}$ According to this approach, the extent of MNE activity increases with increased differences in the relative factor endowments between countries.

For many years, horizontal and vertical models were regarded as two completely disjoint strands in the MNE literature. The milestone in the development of the modern MNE theory was the combination of horizontal and vertical approaches into the unified framework in which firms were able to choose between national, horizontal and vertical strategies. This was done by Markusen (2002) who called this broader framework the knowledge capital (KC) model. In his model, three types of firms; national firms, horizontally-integrated MNEs and vertically- integrated MNEs arise endogenously in the equilibrium in response to various combinations of home and host country characteristics.

According to the $\mathrm{KC}$ model, national firms exporting to each other's market would dominate both types of MNEs when countries were similar in economic size and relative factor endowments and trade costs were low. Horizontally integrated MNEs would dominate when countries were similar in economic size and in relative factor endowments and trade costs were high. Finally, if countries were similar in size but dissimilar in relative factor endowments vertically integrated MNEs would be the dominant type.

In the more recent years, the $\mathrm{KC}$ model was extended in many directions. ${ }^{3}$ However, probably one of the most important recent extensions of the $\mathrm{KC}$ model was the incorporation of physical capital as an additional factor of production along with human capital and unskilled labor proposed by Bergstrand and Egger (2007, 2013). This extension allows comparing directly the KC model with the earlier models of horizontally and vertically-integrated MNEs in which differences in relative factor endowments were determined by physical capital to labor ratios only.

Empirical studies that tried to validate the predictions of the modern MNE theories did not start, however, until the early 1990s. These studies initially focused mainly on US multinationals while MNEs from other counties received relatively less attention. The empirical studies on determinants of MNE activity were initiated by Brainard (1993a, b, 1997). She tested theoretical predictions derived from the models of both horizontally and vertically integrated MNEs. According to her findings, the majority of the US MNEs are integrated horizontally and not vertically. Subsequently, her results were called into question by Carr et al. (2001) who estimated specifications directly derived from the more general model and found that the US MNEs were integrated not only horizontally but also vertically. The importance of vertical FDI was confirmed later in the follow up studies by Braconier et al. (2005) and Davies (2008).

\footnotetext{
${ }^{2}$ The first models of vertically-integrated MNEs were developed by Helpman (1984) and Helpman and Krugman (1985). These models were later extended by, inter alia, Zhang and Markusen (1999), Markusen and Venables (2000) and Markusen (2002).

${ }^{3}$ For example, the extensions of the original knowledge capital model can be found in recent studies by Bergstrand and Egger (2007, 2013), Markusen and Strand (2009), Markusen and Stähler (2011), and Chen et al. (2012).
} 
Table 1 Definitions and summary statistics of dependent and explanatory variables. Source: own elaboration

\begin{tabular}{llrrrr}
\hline Explanatory variable & Definition & Mean & SD & Min & Max \\
\hline MNE & Number of firms with foreign capital & 89.643 & 235.845 & 0 & 1812 \\
HLDIFF & Human capital per worker difference & 0.210 & 0.149 & 0.001 & 0.555 \\
KLDIFF & Capital per worker difference & 76.606 & 66.593 & 0.131 & 329.417 \\
SIMILARITY & Helpman GDP size dispersion index & 0.205 & 0.132 & 0.026 & 0.488 \\
GDPSUM & Sum of parent country and Poland's GDPs & 0.675 & 0.236 & 0.304 & 1.381 \\
DISTANCE & Geographic distance of each parent coun- & 925.750 & 535.536 & 365 & 2137 \\
& try’s capital city from Warsaw & & & & \\
HFINDEX & Hofstede index & 114.250 & 33.582 & 71 & 166 \\
\hline
\end{tabular}

More recently, the determinants of inward FDI have been studied empirically also for other countries. In the context of Central and East European countries (CEECs), there exists a relatively large number of cross-country studies for the whole region including, inter alia, Lansbury et al. (1996), Brenton et al. (1999), Benacek et al. (2000), Resmini (2000), Garibaldi et al. (2001), Bevan and Estrin (2004), Carstensen and Toubal (2004), Cieślik and Ryan (2004), Baniak et al. (2005), Gorbunova et al. (2012), Wach and Wojciechowski (2016) and more recently by Ascani et al. (2017), Stack et al. (2017) and Tang (2017). ${ }^{4}$ However, the empirical evidence for individual CEECs is more scarce. In particular, determinants of MNE activity in Poland were studied by Torrisi et al. (2009) and Cieślik (2017). However, with the exception of the recent study by Cieślik (2017), which focused on FDI from the old EU-15 member states, the previous studies made no attempts to validate empirically the predictions derived from the modern MNE theories and discriminate between competing theoretical models of multinational enterprise.

Thus, further research on FDI determinants in Poland would definitely be of interest. It seems clear that the process of integration into the EU should have a significant impact on the amount of FDI located in Poland. This is mostly due to the fact that through a GDP growth and reduction in trade costs such as transportation costs and tariffs, it led to a substantial expansion of market size. However, at the same time the accession to the EU reduced the differences between Poland and the other EU member countries in terms of unit labor costs. This in turn is expected to decrease the inflows of vertical FDI and increase inward horizontal FDI from the new European Union members to the countries that joined the community in the year 2004 and afterwards.

In contrast to previous studies that relied on imperfect proxy variables for differences in relative factor endowments between countries, in this paper we use actual data on both physical and human capital stocks extracted from the most recent Penn

\footnotetext{
4 The extensive meta-analysis of the previous empirical studies on FDI determinants in the CEE countries published in the 1996-2015 period has been provided by Tokunaga and Iwasaki (2017). In Table 1, they show the country coverage and the dependent and explanatory variables used in particular studies.
} 
World Table 9.0. The table is the definitive source for real national accounts data. The national accounts for each country, expressed initially in their own currencies, are adjusted using detailed price data to obtain real national accounts in a common currency (U.S. dollars) across countries. These data are invaluable for making international comparisons of Gross Domestic Product (GDP). Moreover, the Penn World Table 9.0 offers also internationally comparable data on physical and human capital stocks that are used in this study along with the GDP data. Finally, in this paper, in addition to traditional country-pair characteristics such as relative and absolute market size, differences in relative factor endowments and trade costs, we also take into account the potential effects of cultural similarity between the host and partner countries that may affect the cost of FDI.

\section{Data sources and statistical methodology}

The competing theoretical models discussed in the previous section predict how MNE activity can be related on a bilateral basis to combined market sizes, differences in economic country size, differences in relative factor endowments and trade costs. Both horizontal and vertical models of multinational enterprise can be nested into and regarded as two special cases of the knowledge capital model and estimated using a panel of cross-country observations for Poland over the period 1990-2014. The first year of the sample-1990 was chosen since it was the year after the Berlin Wall fall and the beginning of radical economic and political reforms in Central and Eastern Europe, while the last year of the sample_-2014 was chosen since it was the year after the last enlargement of the European Union to the East to include Croatia.

The majority of country-pair characteristics that determine the extent of MNE activity in pure horizontal and vertical models are also present in the hybrid knowledge-capital model. However, their expected impacts may differ between particular models. Hence, testing whether the market seeking or the efficiency seeking motive helps explaining the pattern of MNE activity in Poland of firms originating from the new EU member states can be done using the signs and statistical significance of the estimated coefficients on particular explanatory variables.

The most important variables that allow differentiating between the competing theoretical models include similarity in economic size between the parent and the host countries and differences in their relative factor endowments. According to both pure horizontal and hybrid knowledge capital models, there is a positive relationship between similarity in the relative country size and the extent of MNE activity in the host country. On the other hand, in the pure vertical model, similarity in country size does not play any role in the determination of the extent of MNE activity. In this paper, we employ the size dispersion index proposed by Helpman (1987) to measure similarity in economic size between countries. The value of his index ranges between 0 and 0.5 and is maximized when countries are of the same size. The Helpman size similarity index (SIMILARITY) is calculated using data on output-side real GDP at chained PPPs and expressed in constant 2011 US dollars. The GDP data comes from the Penn World Table (PWT) 9.0 available at www.ggdc.net/pwt. 
Other key explanatory variables are differences in relative factor endowments between the home and the host countries. According to both pure vertical and hybrid knowledge capital models, there is a positive relationship between differences in the relative factor endowments and the extent of MNE activity in the host country. At the same time, in the pure horizontal model, differences in the relative factor endowments do not matter for the determination of the extent of MNE activity. Despite the ongoing process of economic convergence between Poland and other new EU member states differences in relative factor endowments between the countries are still substantial. Therefore, positive signs of estimated coefficients on differences in relative factor endowments should be expected.

In this study, we use the measures of differences in the relative factor endowments for both human (HLDIFF) and physical capital per worker (KLDIFF), respectively. The difference in human capital endowments between the home country and Poland is calculated employing the human capital index. This index is based on the years of schooling and returns to education. The relative physical capital endowment in each country is calculated by dividing the capital stock expressed in PPPs in thousands of constant 2011 US dollars by the number of people employed. The data on relative factor endowments also come from the Penn World Table (PWT) 9.0.

In our estimating equation, we also include a number of control variables. In particular, in order to control for the absolute economic country size, we include the sum of Poland's and the home country's GDPs (GDPSUM). According to all theoretical models, we summarized in the previous section the extent of MNE activity is positively related to the absolute economic size. Hence, we should expect a positive sign on the GDPSUM variable. The sum of Poland's and home country's GDP is calculated using the same GDP data which come from the Penn World Table (PWT) 9.0 and were used previously to calculate the similarity index and is expressed in billions of constant 2011 US dollars.

In order to control for the potential effects of transport and other distance related costs such as communication and monitoring, we include two measures of distance: physical geographic distance (DISTANCE) and cultural distance, measured by the Hofstede index (HFINDEX), between the home country and Poland. The existing theory of multinational enterprise does not yield, however, clear predictions concerning the impact of various types of distance on the extent of MNE activity in the host country. Previous empirical studies suggest mostly that negative signs of the estimated coefficients on distance variables should be expected. The physical geographic distance is measured in the simplest possible way by calculating a "as the crow flies" distance between European capitals and the capital city of Poland-Warsaw. This distance is expressed it in kilometers and the data comes from the distance calculator available at: http://www.indo.com/distance.

To proxy for the cultural distance we use the Hofstede index that is composed of six different dimensions that measure various aspects of cultural similarity: (1) Power Distance Index (PDI), (2) Individualism versus Collectivism (IDV), (3) Masculinity versus Femininity (MAS), (4) Uncertainty Avoidance Index (UAI), (5) Long Term Orientation versus Short Term Normative Orientation (LTO), (6) Indulgence versus Restraint (IND). The interpretation of particular components of Hofstede 
Table 2 Pairwise correlations between variables

\begin{tabular}{llllllll}
\hline Variable & MNE & HLDIFF & KLDIFF & SIMILARITY & GDPSUM & DISTANCE & HFINDEX \\
\hline MNE & 1 & 0.4618 & 0.6619 & -0.0148 & 0.3353 & 0.2481 & -0.2805 \\
HLDIFF & & 1 & 0.5679 & -0.1251 & 0.0182 & 0.3258 & -0.2151 \\
KLDIFF & & & 1 & -0.1059 & 0.4681 & 0.3729 & -0.4331 \\
SIMILARITY & & & 1 & 0.2253 & -0.4804 & -0.2498 \\
GDPSUM & & & & & 1 & -0.1354 & -0.1132 \\
DISTANCE & & & & & & 1 & -0.5841 \\
HFINDEX & & & & & & & 1 \\
\hline
\end{tabular}

index is provided in the "Appendix". The country scores on these dimensions are relative as culture can be only used meaningfully by comparison.

In order to obtain the aggregate measure of cultural differences between countries we calculate for each component the absolute differences between Poland and its investment partners and then sum them up into the single index category. ${ }^{5}$ This means that the higher values of the Hofstede index are associated with bigger cultural difference. The data necessary for calculations of this index were obtained from geert-hofstede.com/countries.

Finally, to control for business cycle and policy changes effects such, as joining the EU in 2004, we include individual time effects and to control for country heterogeneity we include country-pair fixed effects. The definitions of dependent and explanatory variables and their summary statistics are summarized in Table 1.

The pairwise correlations between variables used in the empirical study are reported in Table 2. The analysis of these correlations shows that the regressors are not highly correlated and the estimation results are free from the multicollinearity problem.

Our measure of the extent of multinational involvement in Poland's economy is the number of operational entities with foreign capital participation obtained from the Polish Central Statistical Office (CSO). According to the most recent CSO (2015) data in 2014, there were in total 26,464 operational firms with foreign equity of which 3161 firms $(11.9 \%)$ came from the new EU member states. ${ }^{6}$

The top three source countries among the new EU countries were, respectively, Cyprus with 1808 firms (6.8\%), the Czech Republic with 613 firms (2.3\%), and Slovakia with 195 firms $(0.7 \%)$. The majority of multinational enterprises as well as the foreign equity were concentrated in service and manufacturing activities and foreign involvement in the primary sector was negligible.

The dependent variable assumes non-negative integer values and the presence of zeros and small values, especially in the early years of the sample, suggests that

\footnotetext{
5 As the original data on various cultural dimensions were not available for Cyprus, hence they had to be replaced by the respective values for Greece-the closest country in terms of culture.

6 The new EU member countries include: Bulgaria, Croatia, Cyprus, the Czech Republic, Estonia, Hungary, Latvia, Lithuania, Malta, Slovakia, Slovenia, and Romania.
} 
Table 3 Estimates of the NB model for the period 1990-2014: full sample. Source: own elaboration

\begin{tabular}{|c|c|c|c|}
\hline Explanatory variable & (1) & (2) & (3) \\
\hline HLDIFF & $\begin{array}{l}1.494 * * * \\
(2.78)\end{array}$ & $\begin{array}{l}1.797 * * * \\
(3.61)\end{array}$ & $\begin{array}{l}0.827 \\
(1.30)\end{array}$ \\
\hline KLDIFF & $\begin{array}{l}0.012 * * * \\
(6.61)\end{array}$ & $\begin{array}{l}0.013 * * * \\
(8.63)\end{array}$ & $\begin{array}{l}0.009 * * * \\
(7.15)\end{array}$ \\
\hline SIMILARITY & $\begin{array}{l}2.037 * * \\
(2.06)\end{array}$ & $\begin{array}{l}12.321 * * * \\
(9.45)\end{array}$ & $\begin{array}{l}13.765 * * * \\
(7.50)\end{array}$ \\
\hline GDPSUM & $\begin{array}{l}2.411 * * * \\
(5.82)\end{array}$ & $\begin{array}{l}-16.397 * * * \\
(7.72)\end{array}$ & $\begin{array}{l}-8.183 * * * \\
(5.80)\end{array}$ \\
\hline DISTANCE & $\begin{array}{l}-0.000 \\
(0.50)\end{array}$ & $\begin{array}{l}-0.001 * * \\
(2.49)\end{array}$ & $\begin{array}{l}0.001 * * * \\
(3.23)\end{array}$ \\
\hline HFINDEX & $\begin{array}{l}0.003 \\
(0.90)\end{array}$ & $\begin{array}{l}-0.003 \\
(0.94)\end{array}$ & $\begin{array}{l}0.005 \\
(0.78)\end{array}$ \\
\hline Constant & $\begin{array}{l}0.055 \\
(0.06)\end{array}$ & $\begin{array}{l}3.563 * * * \\
(3.31)\end{array}$ & $\begin{array}{l}-2.185 \\
(1.20)\end{array}$ \\
\hline Time-specific effects & No & Yes & Yes \\
\hline Country-specific effects & No & No & Yes \\
\hline Loglikelihood & -1373.741 & -1296.868 & -2372.102 \\
\hline Pseudo R2 & 0.110 & 0.160 & 0.283 \\
\hline Alpha $\alpha$ (z-stat) & $\begin{array}{l}0.965 \\
(12.19)\end{array}$ & $\begin{array}{l}0.605 \\
(11.50)\end{array}$ & $\begin{array}{l}0.128 \\
(8.59)\end{array}$ \\
\hline LR test ( $p$ value) & $\begin{array}{l}9157.23 \\
(0.000)\end{array}$ & $\begin{array}{l}6038.67 \\
(0.000)\end{array}$ & $\begin{array}{l}997.56 \\
(0.000)\end{array}$ \\
\hline Chi2 test for country effects ( $p$ value) & & & $\begin{array}{l}721.58 \\
(0.000)\end{array}$ \\
\hline Chi2 test for time effects ( $p$ value) & & $\begin{array}{l}202.05 \\
(0.000)\end{array}$ & $\begin{array}{l}326.16 \\
(0.000)\end{array}$ \\
\hline
\end{tabular}

Dependent variable: the number of multinational enterprises; $\mathrm{N}=300$ in all specifications

**Significant at the $5 \%$ level of significance; ***significant at the $1 \%$ level of significance, $\mathrm{z}$-statistics in parentheses

traditional estimation techniques, such as OLS for example, may not be appropriate in this case. Instead, the use of count models in this empirical study is a more appropriate choice. The most popular count models include the Poisson and negative binomial (NegBin) models. The Poisson model is nested in the NegBin model. The standard likelihood ratio (LR) test can be used to determine the proper estimation format. Both the Poisson and NegBin models were estimated, however, the LR test always favored the NegBin model over the Poisson model. Hence, we report only the NegBin model estimates in the next section. 
Table 4 Estimates of the NB model for the period 1990-2014: limited sample (without Cyprus and Malta). Source: own elaboration

\begin{tabular}{|c|c|c|c|}
\hline Explanatory variable & $(1)$ & (3) & (4) \\
\hline HLDIFF & $\begin{array}{l}1.295 * * \\
(2.36)\end{array}$ & $\begin{array}{l}1.384 * * * \\
(2.82)\end{array}$ & $\begin{array}{l}-0.213 \\
(0.40)\end{array}$ \\
\hline KLDIFF & $\begin{array}{l}0.004 * * \\
(1.98)\end{array}$ & $\begin{array}{l}0.008 * * * \\
(4.08)\end{array}$ & $\begin{array}{l}0.008 * * * \\
(7.08)\end{array}$ \\
\hline SIMILARITY & $\begin{array}{l}1.663 \\
(1.55)\end{array}$ & $\begin{array}{l}14.534 * * * \\
(9.21)\end{array}$ & $\begin{array}{l}10.649 * * * \\
(6.25)\end{array}$ \\
\hline GDPSUM & $\begin{array}{l}2.594 * * * \\
(5.99)\end{array}$ & $\begin{array}{l}-17.700 * * * \\
(7.42)\end{array}$ & $\begin{array}{l}-2.480^{*} \\
(1.80)\end{array}$ \\
\hline DISTANCE & $\begin{array}{l}-0.001 * * * \\
(4.40)\end{array}$ & $\begin{array}{l}-0.002 * * * \\
(7.38)\end{array}$ & $\begin{array}{l}-0.000 \\
(0.68)\end{array}$ \\
\hline HFINDEX & $\begin{array}{l}-0.004 \\
(0.97)\end{array}$ & $\begin{array}{l}-0.006 \\
(1.58)\end{array}$ & $\begin{array}{l}0.017 * * \\
(2.45)\end{array}$ \\
\hline Constant & $\begin{array}{l}2.210 * * \\
(2.44)\end{array}$ & $\begin{array}{l}4.144 * * * \\
(3.55)\end{array}$ & $\begin{array}{l}-4.198 * * \\
(2.43)\end{array}$ \\
\hline Time-specific effects & No & Yes & Yes \\
\hline Country-specific effects & No & No & Yes \\
\hline Loglikelihood & -1115.605 & -1048.458 & -880.116 \\
\hline Pseudo R2 & 0.092 & 0.147 & 0.284 \\
\hline Alpha $\alpha$ (z-stat) & $\begin{array}{l}0.885 \\
(10.81)\end{array}$ & $\begin{array}{l}0.533 \\
(10.06)\end{array}$ & $\begin{array}{l}0.075 \\
(6.11)\end{array}$ \\
\hline LR test ( $p$ value) & $\begin{array}{l}3501.92 \\
(0.000)\end{array}$ & $\begin{array}{l}2228.57 \\
(0.000)\end{array}$ & $\begin{array}{l}216.55 \\
(0.000)\end{array}$ \\
\hline Chi2 test for country effects ( $p$ value) & & & $\begin{array}{l}636.06 \\
(0.000)\end{array}$ \\
\hline Chi2 test for time effects ( $p$ value) & & $\begin{array}{l}171.74 \\
(0.000)\end{array}$ & $\begin{array}{l}727.93 \\
(0.000)\end{array}$ \\
\hline
\end{tabular}

Dependent variable: the number of multinational enterprises; $\mathrm{N}=250$ in all specifications

$* *$ Significant at the $5 \%$ level of significance; ***Significant at the $1 \%$ level of significance, $\mathrm{z}$-statistics in parentheses

\section{Empirical results}

In this section, we report the following two sets of estimation results. First, in Table 3 we report the results obtained for the full sample of the new EU member states including two non-Central and East European countries: Cyprus and Malta. Then, in Table 4 we report estimation results obtained for the limited sample of countries that excludes both Cyprus and Malta as they are different from the CEE countries. These two small island economies serve as tax havens within the EU and therefore the number of foreign firms registered in these countries which operate in Poland may be overrepresented in the sample.

The benchmark estimation results generated by the traditional NB approach on the pooled sample that do not allow controlling for individual time and countrypair effects are shown in column (1) of Table 3. The majority of the estimated 
coefficients on our explanatory variables are statistically significant. Some of them are significant already at the $1 \%$ level and display the signs that favor the knowledge capital model in which both market access and cost reducing motives determine FDI over the pure models of vertically- and horizontally-integrated multinational firms. In particular, both the positive sign of the estimated parameter on the measure of differences in relative factor endowments and on the measure of similarity in terms of market size suggest that multinational activity in Poland increases with differences in human and physical capital to labor ratios and the similarity in GDPs. Interestingly, none of the estimated coefficients on our distance measures is statistically significant in this specification.

In column (2), we report the results obtained controlling for individual time specific effects represented by dummy variables for specific years of the sample. In qualitative terms the inclusion of time effects, however, does not change much our previous conclusions, obtained on the basis of our baseline estimates reported in column (1), concerning impact of particular country-pair characteristics on the extent of foreign involvement in Poland and the preferred theoretical model. However, the inclusion of time effects changes the sign of the estimated coefficient on the GDPSUM variable. In addition, the estimated coefficient on the physical distance now becomes statistically significant at the 5\% level and displays a negative sign which is in line with the vertical reason for FDI.

In column (3), we check the robustness of our estimates by including both timespecific and country-specific fixed effects. These estimation results differ, however, from both the benchmark results reported in column (1) and the results reported in column (2) as the estimated coefficients on the measures of differences in human capital endowments now loses its previous statistical significance. In addition, the estimated coefficient on the physical distance variable changes its sign from negative to positive and becomes statistically significant at the $1 \%$ level which would suggest the dominance of the horizontal reason for undertaking FDI in Poland.

In Table 4, we study the robustness of the estimation results reported in Table 3 by excluding Cyprus and Malta from the sample. The particular columns in Table 4 are the direct counterparts of columns in Table 3.

In column (1) of Table 4 report the benchmark estimates on the pooled dataset obtained without controlling for individual time and country-pair fixed effects. These results look similar to the results reported in column (1) of Table 3. Again, almost all estimated coefficients are statistically significant already at the $1 \%$ level and display expected signs. However, the exceptions are the measure of similarity in terms of market size and the measure of cultural difference which are not statistically significant at all. In particular, the lack of statistical significance of the measure of similarity in terms of market size suggests that only the vertical reasons are important for multinationals from the new EU member countries that invested in Poland. This conclusion would be further reinforced by the negative and statistically significant coefficient on the distance variable that would support the vertical model. Hence, these findings differ from the findings reported in column (1) of Table 3, as they do not support the knowledge capital model in which both differences in relative factor endowments and similarity in market size play a key role in determination of the extent of multinational activity but rather favor the vertical model. 
In column (2), we report the estimation results obtained from the specification in which we controlled for individual year specific effects. The inclusion of time effects makes the measure of the similarity in country size statistically significant at the $1 \%$ level. This, in turn, would suggest that both horizontal and vertical reasons for multinational activity in Poland are important and the knowledge capital model is preferred to the pure vertical and horizontal models. However, the vertical motive seems to dominate as the estimated parameter on the distance variable remains negative and statistically significant, which is similar to the results reported in column (2) of Table 3.

Finally, in column (3), we show the results obtained from the specification in which we controlled for both country-specific effects and time-specific effects. In this case, the estimation results differ from the results reported in column (1) as now only one measure of differences in relative factor endowments-differences in capital to labor ratios-is statistically significant at the $1 \%$ level and displays the expected positive sign while the second measure is not significant at all. The estimated coefficients on the measure of similarity in market size also display the expected positive signs and remain statistically significant at the $1 \%$ level. These findings are similar to the findings reported in column (3) of Table 3.

However, the important difference is that the estimated parameter the measure of physical distance loses its previous statistical significance while the parameter on the measure of cultural distance displays a positive sign and becomes statistically significant but only at the $5 \%$ level. These empirical results suggest that both differences in the capital to labor ratios as well as the market access are important for multinational firms based in the new EU countries that undertake FDI in Poland. Hence, these results support the knowledge capital model of multinational enterprise.

\section{Conclusions}

The advances in the NTT allowed incorporating MNEs into the mainstream international trade theory giving rise to the modern theory of multinational enterprise according to which MNEs arise endogenously in response to various country characteristics such as relative factor endowments, economic size, and trade and investment costs. The theoretical studies identified two main types of MNEs: horizontallyintegrated firms that follow the market seeking strategy and produce the same goods in multiple locations to avoid trade costs and vertically-integrated firms that follow the efficiency seeking strategy and fragment geographically their production processes by stages differing in terms of their factor intensity.

This study used the negative binomial model to examine empirically the main reasons for multinational activity of firms originating from the new EU member states in Poland during the period 1990-2014. The estimated specification of the empirical model was based on the modified knowledge-capital model with two types 
of capital in which both horizontally- and vertically-integrated firms could coexist in equilibrium. In contrast to previous studies that used various proxy variables for differences in relative factor endowments in this study, we used actual data on both physical and human capital endowments extracted from the PennWorld Tables 9.0.

The estimated parameters on the differences in the physical capital per worker variable turned out to be positive and statistically significant in all estimated specifications while the estimated parameters on the differences in the human capital per worker variable lost its statistical significance once the country specific fixed effects were controlled for. Nevertheless, the statistical significance of the differences in the physical capital per worker variable confirms the importance of the vertical reason for FDI in Poland. At the same time, the estimated parameter on the measure of similarity in country size remained statistically significant once the country specific fixed effects were controlled for which confirms also the importance of the horizontal reason for FDI in Poland. Therefore, the assembled empirical evidence pointed to both vertical and horizontal motives for undertaking FDI in Poland by MNEs based in the new EU member states. This means that the Polish government should not try to attract only one type of FDI.

Moreover, in contrast to previous studies in this study, we also tried to account for cultural differences that exist between the Poland and investment partner countries in addition to the traditional set of country characteristics such as market size, similarity and factor endowments. However, it was found that in the majority of the estimated specifications the employed measure of cultural distance was not statistically significant. Given the growing criticism of the Hofstede index in the international business literature, the use of this index might be considered the major limitation of the current study. ${ }^{7}$ Therefore, in future studies it would be useful to use alternative measures of cultural similarity that may better capture cultural aspects such the GLOBE index that is able to distinguish cultural values from practices.

Funding Funding was provided by Narodowe Centrum Nauki (Grant No. 2015/19/B/HS4/03230).

Open Access This article is distributed under the terms of the Creative Commons Attribution 4.0 International License (http://creativecommons.org/licenses/by/4.0/), which permits unrestricted use, distribution, and reproduction in any medium, provided you give appropriate credit to the original author(s) and the source, provide a link to the Creative Commons license, and indicate if changes were made.

\footnotetext{
7 For example, see the survey of critical arguments against the use of the Hofstede index provided by Shaiq et al. (2011).
} 
Table 5 Construction of Hofstede Index

Components of Interpretation

Hofstede Index

\begin{tabular}{|c|c|}
\hline DI & $\begin{array}{l}\text { Expresses the degree to which the less powerful members of a society accept and } \\
\text { expect that power is distributed unequally. People in societies exhibiting a large } \\
\text { degree of power distance accept a hierarchical order in which everybody has a place } \\
\text { and which needs no further justification. In societies with low power distance, people } \\
\text { strive to equalize the distribution of power and demand justification for inequalities } \\
\text { of power }\end{array}$ \\
\hline DV & $\begin{array}{l}\text { Measures a preference for a loosely-knit social framework in which individuals are } \\
\text { expected to take care of only themselves and their immediate families versus a } \\
\text { preference for a tightly-knit framework in society in which individuals can expect } \\
\text { their relatives or members of a particular in-group to look after them in exchange for } \\
\text { unquestioning loyalty }\end{array}$ \\
\hline AS & $\begin{array}{l}\text { Represents a preference in society for achievement, heroism, assertiveness and material } \\
\text { rewards for success versus preference for cooperation, modesty, caring for the weak } \\
\text { and quality of life. In the business context, masculinity versus femininity is some- } \\
\text { times also related to as "tough versus tender" cultures }\end{array}$ \\
\hline$\Delta \mathrm{I}$ & $\begin{array}{l}\text { Expresses the degree to which the members of a society feel uncomfortable with uncer- } \\
\text { tainty and ambiguity. The fundamental issue here is how a society deals with the fact } \\
\text { that the future can never be known: should we try to control the future or just let it } \\
\text { happen? Countries exhibiting strong UAI maintain rigid codes of belief and behavior } \\
\text { and are intolerant of unorthodox behavior and ideas. Weak UAI societies maintain a } \\
\text { more relaxed attitude in which practice counts more than principles }\end{array}$ \\
\hline & $\begin{array}{l}\text { Measures society's links with its own past while dealing with the challenges of the pre- } \\
\text { sent and the future. Societies which have low scores on this dimension prefer to main- } \\
\text { tain time-honored traditions and norms while viewing societal change with suspicion. } \\
\text { Those with high scores take a more pragmatic approach: they encourage thrift and } \\
\text { efforts in modern education as a way to prepare for the future. In the business context, } \\
\text { this dimension is related to as "(short term) normative versus (long term) pragmatic" }\end{array}$ \\
\hline & $\begin{array}{l}\text { Measures indulgence which stands for a society that allows relatively free gratifica- } \\
\text { tion of basic and natural human drives related to enjoying life and having fun } \\
\text { versus restraint that stands for a society that suppresses gratification of needs and } \\
\text { regulates it by means of strict social norms }\end{array}$ \\
\hline
\end{tabular}

\section{Appendix}

See Table 5.

\section{References}

Ascani, A., Crescenzi, R., \& Iammarino, S. (2017). The geography of foreign investments in the EU neighbourhood. Tijdschrift voor Economische en Sociale Geografie, 108(1), 76-91.

Baniak, A., Cukrowski, J., \& Herczyński, J. (2005). On the determinants of foreign direct investment in transition economies. Problems of Economic Transition, 48(2), 6-28.

Benacek, V., Gronicki, M., Holland, D., \& Sass, M. (2000). The determinants and impact of foreign direct investment in Central and Eastern Europe: A comparison of survey and econometric evidence. Transnational Corporations, 9(3), 163-212. 
Bergstrand, J. H., \& Egger, P. (2007). A knowledge and physical capital model of international trade flows, foreign direct investment and multinational enterprises. Journal of International Economics, 73(2), 278-308.

Bergstrand, J. H., \& Egger, P. (2013). Shouldn't physical capital also matter for multinational enterprise activity? Review of International Economics, 21(5), 945-965.

Bevan, A. A., \& Estrin, S. (2004). The determinants of foreign direct investment into European transition economies. Journal of Comparative Economics, 32(4), 775-787.

Braconier, H., Norbäck, P. J., \& Urban, D. (2005). Reconciling the evidence on the knowledge capital model. Review of International Economics, 13(4), 770-786.

Brainard, L. S. (1993a). A simple theory of multinational corporations and trade with a tradeoff between proximity and concentration. NBER working paper 4269.

Brainard, L.S. (1993b). An empirical assessment of the factor proportions explanation of multinational sales. NBER working paper 4580.

Brainard, L. S. (1997). An empirical assessment of the proximity concentration tradeoff between multinational sales and trade. American Economic Review, 87(4), 520-544.

Brenton, P., Di Mauro, F., \& Lucke, M. (1999). Economic integration and FDI: An empirical analysis of foreign investment in the EU and in Central and Eastern Europe. Empirica, 26(2), 95-121.

Carr, D. L., Markusen, J. R., \& Maskus, K. E. (2001). Estimating the knowledge capital model of the multinational enterprise. American Economic Review, 91(3), 693-708.

Carstensen, K., \& Toubal, F. (2004). Foreign direct investment in Central and Eastern European countries: A dynamic panel analysis. Journal of Comparative Economics, 32(1), 3-22.

Caves, R. E. (2007). Multinational enterprise and economic analysis. Cambridge: Cambridge University Press.

Chen, Y., Horstmann, I. J., \& Markusen, J. R. (2012). Physical capital, knowledge capital, and the choice between FDI and outsourcing. Canadian Journal of Economics, 45(1), 1-15.

Cieślik, A. (2013). Horizontally integrated MNE and plant heterogeneity. Bank i Kredyt, 44(6), 605-622.

Cieślik, A. (2015a). North-North FDI, exporting and the first mover advantage. Bank $i$ Kredyt, 46(2), 109-128.

Cieślik, A. (2015b). Imperfect competition, productivity differences and proximity-concentration tradeoffs. Ekonomia, 40, 7-30.

Cieślik, A. (2016). Exports versus FDI in Smith-Motta framework, Equilibrium. Quarterly Journal of Economics and Economic Policy, 11(2), 189-218.

Cieślik, A. (2017). Determinants of MNE activity in Poland: The case of firms from EU-15. Entrepreneurial Business and Economics Review, 5(1), 151-167.

Cieślik, A. (2018). Leader-follower model of reciprocal FDI and international trade. Argumenta Oeconomica, 41(2), 91-112.

Cieślik, A., \& Ryan, M. (2004). Explaining Japanese direct investment flows into an enlarged Europe: A comparison of gravity and economic potential approaches. Journal of the Japanese and International Economies, 18, 12-37.

Cieślik, A., \& Ryan, M. (2012). Productivity differences and foreign market entry in an oligopolistic industry. Open Economies Review, 23(3), 531-557.

CSO. (2015). The economic activity of firms with foreign capital participation. Warszawa: Zakład Wydawnictw Statystycznych.

Davies, R. B. (2008). Hunting high and low for vertical FDI. Review of International Economics, 16(2), 250-267.

Dunning, J. H. (1977). The determinants of international production. Oxford Economic Papers, 25(3), 289-336.

Dunning, J. H., \& Lundan, S. M. (2008). Multinational enterprises and the global economy. Cheltenham: Edward Elgar.

Garibaldi, P., Mora, N., Sahay, R., \& Zettelmeyer, J. (2001). What moves capital to transition economies? IMF Staff Papers, 48, 109-145.

Gorbunova, Y., Infante, D., \& Smirnova, J. (2012). New evidence on FDI determinants: An appraisal over the transition period. Prague Economic Papers, 2, 129-149.

Helpman, E. (1984). A simple theory of trade with multinational corporations. Journal of Political Economy, 92, 451-471.

Helpman, E. (1987). Imperfect competition and international trade: Evidence from fourteen industrial countries. Journal of the Japanese and International Economies, 1(1), 62-81. 
Helpman, E., \& Krugman, P. (1985). Market structure and foreign trade: Increasing returns, imperfect competition and the international economy. Cambridge, MA: MIT Press.

Helpman, E., Melitz, M. J., \& Yeaple, S. R. (2004). Export versus FDI with heterogeneous firms. American Economic Review, 94(1), 300-316.

Horstmann, I., \& Markusen, J. R. (1987). Strategic investments and the development of multinationals. International Economic Review, 28, 109-121.

Kemp, M. C. (1962). Foreign direct investment and the national advantage. Economic Record, 38(81), 56-62.

Krugman, P. (1983). The 'new theories' of international trade and multinational enterprise. In D. B. Audretsch \& Ch P Kindleberger (Eds.), The multinational corporation in the 1980s. Cambridge, MA: MIT Press.

Lansbury, M., Pain, N., \& Smidkova, K. (1996). Foreign direct investments in Central Europe since 1990: An econometric study. National Institute Economic Review, 156, 104-113.

MacDougall, G. D. A. (1960). The benefits and costs of private investment from abroad: A theoretical approach. Oxford Bulletin of Economics and Statistics, 22(3), 180-211.

Markusen, J. R. (1984). Multinationals, multi-plant economies and the gains from trade. Journal of International Economics, 16, 205-226.

Markusen, J. R. (1995). The boundaries of multinational enterprise and the theory of international trade. Journal of Economic Perspectives, 9(2), 169-189.

Markusen, J. R. (1998). Multinational firms, location and trade. World Economy, 21(6), 733-756.

Markusen, J. R. (2002). Multinational firms and the theory of international trade. Cambridge, MA: MIT Press.

Markusen, J. R. (2013). Multinational firms. In D. Bernhofen, R. Falvey, D. Greenaway, \& U. Kreickemeier (Eds.), Palgrave handbook of international trade (pp. 236-262). Basingstoke: Palgrave Macmillan.

Markusen, J. R., \& Stähler, F. (2011). Endogenous market structure and foreign market entry. Review of World Economics, 147(2), 195-215.

Markusen, J. R., \& Strand, B. (2009). Adapting the knowledge-capital model of the multinational enterprise to trade and investment in business services. World Economy, 32(1), 6-29.

Markusen, J. R., \& Venables, A. J. (1998). Multinational firms and the new trade theory. Journal of International Economics, 46, 183-203.

Markusen, J. R., \& Venables, A. J. (2000). The theory of endowment, intra-industry and multinational trade. Journal of International Economics, 52, 209-234.

Mundell, R. A. (1957). International trade and factor mobility. American Economic Review, 47(3), 321-335.

National Bank of Poland. (2017). Foreign direct investment inward position at the end of 2015 broken down by country and economic zone. http://www.nbp.pl/homen.aspx?f=/en/publikacje/ziben/ziben .html.

Resmini, L. (2000). The determinants of foreign direct investment in the CEECs: new evidence from sectoral patterns. Economics of Transition, 8(3), 665-689.

Shaiq, H. M. A., Khalid, H. M. S., Akram, A., \& Ali, B. (2011). Why not everybody loves Hofstede? What are the alternative approaches to study of culture? European Journal of Business and Management, 3(6), 101-111.

Stack, M. M., Ravishankar, G., \& Pentecost, E. (2017). Foreign direct investment in eastern European countries: Determinants and performance. Structural Change and Economic Dynamics, 41, 86-97.

Tang, D. (2017). The determinants of European Union (EU) foreign direct investments in the EU countries from Central and Eastern Europe during 1994-2012. Comparative Economic Research, 20(1), 75-99.

Tokunaga, M., \& Iwasaki, I. (2017). The determinants of foreign direct investment in transition economies: A meta-analysis. World Economy, 40(12), 2771-2831.

Torrisi, C. R., Delaunay, C. J., Kocia, A., \& Lubieniecka, M. (2009). FDI in Poland: Determinants and implications for countries in transition. Ekonomia, 23, 3-15.

Wach, K., \& Wojciechowski, L. (2016). Determinants of inward FDI into Visegrad countries: Empirical evidence based on panel data for the years 2000-2012. Economics and Business Review, 2(1), 34-52.

Zhang, K. H., \& Markusen, J. R. (1999). Vertical multinationals and host-country characteristics. Journal of Development Economics, 59(2), 233-252. 
Publisher's Note Springer Nature remains neutral with regard to jurisdictional claims in published maps and institutional affiliations. 